\title{
Key Definitions, Concepts and Setting up of A Company Under Companies Act 2013
}

\author{
Dr. Prof. Jay Girishkumar Dave \\ Assistant Professor, Government Arts and Commerce College, \\ Kadoli, Himatnagar, Gujarat, India
}

\begin{abstract}
The 2013 Act has introduced several new concepts and has also tried to streamline many of the requirements by introducing new definitions. This article covers some of these new concepts and definitions in brief.
\end{abstract}

KEYWORD: Audit, Financial Statements, Investment

\section{Companies}

\subsection{One-Person Company:}

The 2013 Act introduces a new type of entity to the existing list i.e. apart from forming a public or private limited company, the 2013 Act enables the formation of a new entity a 'one-person company' (OPC). An OPC means a company with only one person as its member [section 3(1) of 2013 Act].

\subsection{Private Company:}

The 2013 Act introduces a change in the definition for a private company, inter-alia, the new requirement increases the limit of the number of members from 50 to 200. [ section 2(68) of 2013 Act].

\subsection{Small Company:}

A small company has been defined as a company, other than a public company.

(i) Paid-up share capital of which does not exceed 50 lakh INR or such higher amount as may be prescribed which shall not be more than five crore INR

(ii) Turnover of which as per its last profit-and-loss account does not exceed two crore INR or such higher amount as may be prescribed which shall not be more than 20 crore INR:

As set out in the 2013 Act, this section will not be applicable to the following:

- A holding company or a subsidiary company

- A company registered under section 8

- A company or body corporate governed by any special Act [section 2(85) of 2013 Act]

\subsection{Dormant company:}

The 2013 Act states that a company can be classified as dormant when it is formed and registered under this 2013 Act for a future project or to hold an asset or intellectual property and has no significant accounting transaction. Such a company or an inactive one may apply to the ROC in such manner as may be prescribed for obtaining the status of a dormant company.[Section 455 of 2013 Act]

\section{Roles and responsibilities}

\subsection{Officer:}

The definition of officer has been extended to include promoters and key managerial personnel [section 2(59) of 2013 Act].

\subsection{Key Managerial Personnel:}

The term 'key managerial personnel' has been defined in the 2013 Act and has been used in several sections, thus expanding the scope of persons covered by such sections [section 2(51) of 2013 Act].

\subsection{Promoter:}

The term 'promoter' has been defined in the following ways:

- A person who has been named as such in a prospectus or is identified by the company in the annual return referred to in Section 92 of 2013 Act that deals with annual return; or

- Who has control over the affairs of the company, directly or indirectly whether as a shareholder, director or otherwise; or 
- In accordance with whose advice, directions or instructions the Board of Directors of the company is accustomed to act.

The proviso to this section states that sub-section (c) would not apply to a person who is acting merely in a professional capacity. [Section 2(69) of 2013 Act]

\subsection{Independent Director:}

The term' Independent Director' has now been defined in the 2013 Act, along with several new requirements relating to their appointment, role and responsibilities. Further some of these requirements are not in line with the corresponding requirements under the equity listing agreement [section 2(47), 149(5) of 2013 Act].

\section{Investments}

\subsection{Subsidiary:}

The definition of subsidiary as included in the 2013 Act states that certain class or classes of holding company (as may be prescribed) shall not have layers of subsidiaries beyond such numbers as may be prescribed. With such a restrictive section, it appears that a holding company will no longer be able to hold subsidiaries beyond a specified number [section 2(87) of 2013 Act].

\section{Financial statements}

\subsection{Financial year}

It has been defined as the period ending on the 31 st day of March every year, and where it has been incorporated on or after the 1st day of January of a , the period ending on the 31st day of March of the following year, in respect whereof financial statement of the company or body corporate is made up. [Section 2(41) of 2013 Act] While there are certain exceptions included, this section mandates a uniform accounting year for all companies and may create significant implementation issues.

\subsection{Consolidated financial statements:}

The 2013 Act now mandates consolidated financial statements (CFS) for any company having a subsidiary or an associate or a joint venture, to prepare and present consolidated financial statements in addition to standalone financial statements.

\subsection{Conflicting Definitions:}

There are several definitions in the 2013 Act divergent from those used in the notified accounting standards, such as a joint venture or an associate,, etc., which may lead to hardships in compliance.

\section{Audit and Auditors}

\subsection{Mandatory auditor rotation and joint auditors:}

The 2013 Act now mandates the rotation of auditors after the specified time period. The 2013 Act also includes an enabling provision for joint audits.

\subsection{Non-audit services:}

The 2013 Act now states that any services to be rendered by the auditor should be approved by the board of directors or the audit committee. Additionally, the auditor is also restricted from providing certain specific services.

\subsection{Auditing standards:}

The Standards on Auditing have been accorded legal sanctity in the 2013 Act and would be subject to notification by the NFRA. Auditors are now mandatorily bound by the 2013 Act to ensure compliance with Standards on Auditing.

\subsection{Cognisance to Indian Accounting Standards (Ind AS):}

The 2013 Act, in several sections, has given cognisance to the Indian Accounting Standards, which are standards converged with International Financial Reporting Standards, in view of their becoming applicable in future. For example, the definition of a financial statement includes a 'statement of changes in equity' which would be required under Ind AS. [Section 2(40) of 2013 Act]

\subsection{Secretarial audit for bigger companies:}

In respect of listed companies and other class of companies as may be prescribed, the 2013 Act provides for a mandatory requirement to have secretarial audit. The draft rules make it applicable to every public company with paid-up share capital > Rs. 100 crores*. As specified in the 2013 Act, such companies would be required to annex a secretarial audit report given by a Company Secretary in practice with its Board's report. [Section 204 of 2013 Act]

5.6. Secretarial Standards: The 2013 Act requires every company to observe secretarial standards 
specified by the Institute of Company Secretaries of India with respect to general and board meetings [Section 118 (10) of 2013 Act], which were hitherto not given cognizance under the 1956 Act.

\subsection{Internal Audit:}

The importance of internal audit has been well acknowledged in Companies (Auditor Report) Order, 2003 (the 'Order'), pursuant to which auditor of a company is required to comment on the fact that the internal audit system of the company is commensurate with the nature and size of the company's operations. However, the Order did not mandate that an internal audit should be conducted by the internal auditor of the company. The Order acknowledged that an internal audit can be conducted by an individual who is not in appointment by the company.

The 2013 Act now moves a step forward and mandates the appointment of an internal auditor who shall either be a chartered accountant or a cost accountant, or such other professional as may be decided by the Board to conduct internal audit of the functions and activities of the company.

The class or classes of companies which shall be required to mandatorily appoint an internal auditor as per the draft rules are as follows:

- Every listed company

- Every public company having paid-up share capital of more than 10 crore INR

- Every other public company which has any outstanding loans or borrowings from banks or public financial institutions more than 25 crore INR or which has accepted deposits of more than 25 crore INR at any point of time during the last financial year

\subsection{Audit of items of cost:}

The central government may, by order, in respect of such class of companies engaged in the production of such goods or providing such services as may be prescribed, direct that particulars relating to the utilisation of material or labour or to other items of cost as may be prescribed shall also be included in the books of account kept by that class of companies. By virtue of this section of the 2013 Act, the cost audit would be mandated for certain companies. [section 148 of 2013 Act]. It is pertinent to note that similar requirements have recently been notified by the central government.

\section{Regulators}

\subsection{National Company Law Tribunal (Tribunal or NCLT):}

In accordance with the Supreme Court's (SC) judgment, on 11 May 2010, on the composition and constitution of the Tribunal, modifications relating to qualification and experience, etc. of the members of the Tribunal has been made. Appeals from the Tribunal shall lie with the NCLT. Chapter XXVII of the 2013 Act consisting of section 407 to 434 deals with NCLT and appellate Tribunal.

\subsection{National Financial Reporting Authority (NFRA):}

The 2013 Act requires the constitution of NFRA, which has been bestowed with significant powers not only in issuing the authoritative pronouncements, but also in regulating the audit profession.

\subsection{Serious Fraud Investigation Office (SFIO): The 2013 Act has bestowed legal status to SFIO.}

\section{Mergers and Acquisitions}

The 2013 Act has streamlined as well as introduced concepts such as reverse mergers (merger of foreign companies with Indian companies) and squeeze-out provisions, which are significant. The 2013 Act has also introduced the requirement for valuations in several cases, including mergers and acquisitions, by registered valuers.

\section{Corporate Social Responsibility}

The 2013 Act makes an effort to introduce the culture of corporate social responsibility (CSR) in Indian corporate by requiring companies to formulate a corporate social responsibility policy and at least incur a given minimum expenditure on social activities.

\section{Class Action Suits}

The 2013 Act introduces a new concept of class action suits which can be initiated by shareholders against the company and auditors.

\section{Prohibition of association or partnership of persons exceeding certain number}

The 2013 Act puts a restriction on the number of partners that can be admitted to a partnership at 100 . To be specific, the 2013 Act states that no association or partnership consisting of more than the given 
number of persons as may be prescribed shall be formed for the purpose of carrying on any business that has for its object the acquisition of gain by the association or partnership or by the individual members thereof, unless it is registered as a company under this 1956 Act or is formed under any other law for the time being in force:

As an exception, the aforesaid restriction would not apply to the following:

- A Hindu undivided family carrying on any business

- An association or partnership, if it is formed by professionals who are governed by special acts like the Chartered Accountants Act, etc.[section 464 of 2013 Act] .

\section{Power to Remove Difficulties}

The central government will have the power to exempt or modify provisions of the 2013 Act for a class or classes of companies in public interest. Relevant notification shall be required to be laid in draft form in Parliament for a period of 30 days. The 2013 Act further states no such order shall be made after the expiry of a period of five years from the date of commencement of section 1 of the 2013 Act [section 470 of 2013 Act].

\section{Insider Trading and Prohibition on Forward Dealings}

The 2013 Act for the first time defines 'insider trading and price-sensitive information and prohibits any person including the director or key managerial person from entering into insider trading [section 195 of 2013 Act]. Further, the Act also prohibits directors and key managerial personnel from forward dealings in the company or its holding, subsidiary or associate company [section 194 of 2013 Act].

Incorporation of a company

\section{One-person company}

The 2013 Act introduces a new type of entity to the existing list i.e. apart from forming a public or private limited company, the 2013 Act enables the formation of a new entity 'one-person company' (OPC). An OPC means a company with only one person as its member [section 3(1) of 2013 Act].The draft rules state that only a natural person who is an Indian citizen and resident in India can incorporate an OPC or be a nominee for the sole member of an OPC.

\section{Memorandum of association}

Content: The 2013 Act specifies the mandatory content for the memorandum of association which is similar to the existing provisions of the 1956 Act and refers inter-alia to the following:

- Name of the company with last word as limited or private limited as the case may be

- State in which registered office of the company will be situated

- Liability of the members of the company

However, as against the existing requirement of the 1956 Act, the 2013 Act does not require the objects clause in the memorandum to be classified as the following:

(i) The main object of the company

(ii) Objects incidental or ancillary to the attainment of the main object

(iii) Other objects of the company [section 4(1) of 2013 Act]

The basic purpose in the 1956 Act for such a classification as set out in section 149 of the 1956 Act, is to restrict a company from commencing any business to pursue 'other objects of the company' not incidental or ancillary to the main objects except on satisfaction of certain requirements as prescribed in the 1956 Act like passing a special resolution, filing of declaration with the ROC to the effect of resolution.

Reservation of name: The 2013 Act incorporates the procedural aspects for applying for the availability of a name for a new company or an existing company in sections 4(4) and 4(5) of 2013 Act.

\section{Articles of Association}

The 2013 Act introduces the entrenchment provisions in respect of the articles of association of a company. An entrenchment provision enables a company to follow a more restrictive procedure than passing a special resolution for altering a specific clause of articles of association. A private company can include entrenchment provisions only if agreed by all its members or, in case of a public company, if a special resolution is passed [section 5 of 2013 Act].

\section{Incorporation of Company}

The 2013 Act mandates inclusion of declaration to the effect that all provisions of the 1956 Act have been 
complied with, which is in line with the existing requirement of 1956 Act.

Additionally, an affidavit from the subscribers to the memorandum and from the first directors has to be filed with the ROC, to the effect that they are not convicted of any offence in connection with promoting, forming or managing a company or have not been found guilty of any fraud or misfeasance, etc., under the 2013 Act during the last five years along with the complete details of name, address of the company, particulars of every subscriber and the persons named as first directors.

The 2013 Act further prescribes that if a person furnishes false information, he or she, along with the company will be subject to penal provisions as applicable in respect of fraud i.e. section 447 of 2013 Act [section 7(4) of 2013 Act; Also refer the chapter on other areas]

\section{Formation of a company with charitable objects} An OPC with charitable objects may be incorporated in accordance with the provisions of the 2013 Act. New objects like environment protection, education, research, social welfare etc., have been added to the existing object for which a charitable company could be incorporated.

As against the existing provisions under which a company's license could be revoked, the 2013 Act provides that the license can be revoked not only where the company contravenes any of the requirements of the section but also where the affairs of the company are conducted fraudulently or in a manner violative of the objects of the company or prejudicial to public interest. The 2013 Act thus provides for more stringent provisions for companies incorporated with charitable objects [section 8 of 2013 Act].

The 2013 Act introduces a new form of entity 'oneperson company' and incorporates certain new provisions in respect of memorandum and articles of association. For instance, the concept of including entrenchment provisions in the articles of association has been introduced.

\section{Commencement of business, etc}

The existing provisions of the 1956 Act as set out in section 149 which provide for requirement with respect to the commencement of business for public companies that have a share capital would now be applicable to all companies.

The 2013 Act empowers the ROC to initiate action for removal of the name of a company in case the company's directors have not filed the declaration related to the payment of the value of shares agreed to be taken by the subscribers to the memorandum and that the paid-up share capital of the company is not less than the prescribed limits as per the 2013 Act, within 180 days of its incorporation and if the ROC has reasonable cause to believe that the company is not carrying on business or operations [section 11 of 2013 Act].

\section{Registered office of company}

Where a company has changed its name in the last two years, the company is required to paint, affix or print its former names along with the new name of the company on business letters, bill heads, etc. However, the 2013 Act is silent on the time limit for which the former name needs to be kept [section 12 of 2013 Act].

\section{Alteration of memorandum}

The 2013 Act imposes additional restriction on the alteration of the object clause of the memorandum for a company which had raised money from the public for one or more objects mentioned in the prospectus and has any unutilized money. The 2013 Act specifies that along with obtaining an approval by way of a special resolution, a company would be required to ensure following if it intends to alter its object clause:

Publishing the notice of the aforesaid resolution stating the justification of variation in two newspapers

Exit option can be given to dissenting shareholders by the promoters and shareholders having control in accordance with the regulations to be specified by the Securities and Exchange Board of India (SEBI) [section 13 of 2013 Act].

\section{Subsidiary company not to hold shares in its holding company}

The existing provision of section 42 of the 1956 Act which prohibits a subsidiary company to hold shares in its holding company continues to get acknowledged in the 2013 Act. Thus, the earlier concern that if a subsidiary is a body corporate, it may hold shares in another body corporate which is the subsidiary's 
holding company continues to apply [section 19 of 2013 Act].

\section{Prospectus and public offer}

The 2013 Act has introduced a new section [section $23]$ to explicitly provide the ways in which a public company or private company may issue securities. This section explains that a public company may issue securities in any of the following manners:

- To public through prospectus

- Through private placement

- Through rights issue or a bonus issue.

For private companies, this section provides that it may issue securities through private placement, by way of rights issue or bonus issue.

Section 23 also provides that compliance with provisions of part I of chapter III is required for the issue of securities to public through prospectus. For private placement compliance, with the provisions of part II of chapter III are required.

The 2013 Act also introduces certain changes with respect to prospectus and public offers aimed at enhancing disclosure requirements as well as streamlining the process of issuance of securities.

\section{Issue of prospectus}

Currently, the matters and reports to be included in the prospectus are specified in parts I and II of Schedule II of the 1956 Act. In the 2013 Act, the information to be included in the prospectus is specified in section 26 of 2013 Act. The 2013 Act mandates certain additional disclosures:

Any litigation or legal action pending or taken by a government department or a statutory body during the last five years immediately preceding the year of the issue of prospectus against the promoter of the company

Sources of promoter's contribution The 2013 Act have also relaxed the disclosure requirements in some areas. Examples of certain disclosures not included in the 2013 Act are as follows. Particulars regarding the company and other listed companies under the same management, which made any capital issues during the last three years Export possibilities and export obligations
Details regarding collaboration

The 2013 Act states that the report by the auditors on the assets and liabilities of business shall not be earlier than 180 days before the issue of the prospectus [section 26 (1) (b)(iii) of 2013 Act]. The 1956 Act currently requires that the report will not be earlier than 120 days before the issue of the prospectus.

\section{Variation in terms of contract or objects}

The 2013 Act states that a special resolution is required to vary the terms of a contract referred to in the prospectus or objects for which the prospectus was issued [section 27 (1) of 2013 Act]. The 1956 Act currently requires approval in a general meeting by way of an ordinary resolution. The 2013 Act also requires that dissenting shareholders shall be given an exit offer by promoters or controlling shareholders [section 27 (2) of 2013 Act].

\section{Offer of sale of shares by certain members of the company}

The 2013 Act includes a new section under which members of a company, in consultation with the board of directors, may offer a part of their holding of shares to the public. The document by which the offer of sale to the public is made will be treated as the prospectus issued by the company. The members shall reimburse the company all expenses incurred by it [section 28 of 2013 Act].

\section{Shelf prospectus}

The 2013 Act extends the facility of shelf prospectus by enabling SEBI to prescribe the classes of companies that may file a shelf prospectus. The 1956 Act currently limits the facility of shelf prospectus to public financial institutions, public sector banks or scheduled banks [section 31 (1) of 2013 Act].

\section{Global depository receipts (GDRs)}

The 2013 Act includes a new section to enable the issue of depository receipts in any foreign country subject to prescribed conditions [section 41 of 2013 Act]. Currently, the provisions of section 81 of the 1956 Act relating to further issue of shares are being used in conjunction with the requirements mandated by SEBI for the issuance of depository receipts. In several aspects across the 2013 Act, it appears that the 2013 Act supplements the powers of SEBI by incorporating requirements already mandated by SEBI. 


\section{Private placement}

The 2013 Act requires that certain specified conditions are complied with in order to make an offer or invitation of offer by way of private placement or through the issue of a prospectus.

The offer of securities or invitation to subscribe securities in a financial year shall be made to such number of persons not exceeding 50 or such higher number as may be prescribed \{excluding qualified institutional buyers, and employees of the company being offered securities under a scheme of employees stock option in a financial year and on such conditions (including the form and manner of private placement) as may be prescribed $\}$. This provision of the 2013 Act is in line with the existing provision of the 1956 Act.

The allotments with respect to any earlier offer or invitation may have been completed.

All the money payable towards the subscription of securities shall be paid through cheque, demand draft or any other banking channels but not by cash.

The offers shall be made only to such persons whose names are recorded by the company prior to the invitation to subscribe, and that such persons shall receive the offer by name.

The company offering securities shall not release any advertisements or utilize any media, marketing or distribution channels or agents to inform the public at large about such an offer [section 42 of 2013 Act].

Share capital and debentures

The chapter on share capital and debentures introduces some key changes in the 2013 Act. To illustrate, the 2013 Act does not give any cognisance to the existing requirement of section 90 of the 1956 Act that provided some saving grace to private companies. Therefore, the applicability of following sections of the 2013 Act is no longer restricted to public companies and private companies which are subsidiaries of a public company and are now applicable to private companies also.

\section{Voting rights}

The provisions of 2013 Act regarding voting rights are similar to the existing section 87 of the 1956 Act. The only change noted in the 2013 Act is the removal of distinction provided by the 1956 Act with respect to the entitlement to vote in case the company fails to pay dividend to its cumulative and non-cumulative preference share holders [section 47 of 2013 Act]

The provisions regarding private placement and additional disclosures in prospectus will also help to strengthen the capital markets.

The 2013 Act proposes to re-instate the existing concept of shares with differential voting rights. Pursuant to this section the company may face hardship with regards to computation of proportionate voting rights.

\section{Variation of shareholder's rights}

Similar to the other provisions of the 1956 Act, the 2013 Act acknowledges the requirements of section 106 of the 1956 Act with an additional requirement in respect of those classes of share holders whose rights are affected pursuant to any variation. The proviso to section 48(1) of 2013 Act states that if the variation by one class of shareholders affects the rights of any other class of shareholders, the consent of threefourths of such other class of shareholders shall also be obtained and the provisions of this section shall apply to such variation.

\section{Application of premiums received on issue of shares}

The 2013 Act lays down a similar requirement in section 52 as that of the section 78 of the 1956 Act in respect of application of premiums received on issue of shares; however, the section of 2013 Act has a nonobstante provision in respect of certain class of companies which would be prescribed at a later date. The 2013 Act states that these classes of companies would not be able to apply the securities premium towards the below specified purposes, unless the financial statements are in compliance with the accounting standards issued under section 133 of 2013 Act:

- Paying up unissued equity shares of the company as fully paid bonus shares

- Writing off the expenses of or the commission paid or discount allowed on any issue of equity shares of the company

- Purchase of its own shares or other securities

The 2013 Act restricts the application of securities premium for a certain class of companies if they fail to comply with the accounting standards. The 2013 Act continues to state that securities premium amount 
can be utilized for purpose of writing off preliminary expenses. However, in view of the requirements of accounting standard 26, intangible asset, the requirement of this sub-section appears to be superfluous.

\section{Prohibition on issue of shares at a discount}

Companies would no longer be permitted to issue shares at a discount. The only shares that could be issued at a discount are sweat equity wherein shares are issued to employees in lieu of their services [section 53 and Section 54 of 2013 Act].

Further, explanations I and II to the existing section 79A of the 1956 Act that prescribe the provisions in respect of sweat equity have not been included in the 2013 Act. Explanation I defined company for the purpose of this section and explanation II defined sweat equity.

\section{Issue and redemption of preference shares}

The existing requirement of sections 80 and $80 \mathrm{~A}$ of the 1956 Act with respect to the issue and redemption of preference shares continues to be acknowledged by the 2013 Act. The 2013 Act reiterates the existing requirement that a company cannot issue preference shares with a redemption date of beyond 20 years. However, it gives an exemption for cases where preference shares have been issued in respect of infrastructure projects. Infrastructure projects have been defined in Schedule VI of the 2013 Act and these shares would be subject to redemption at such percentage as prescribed on an annual basis at the option of such preference shareholders.

Further, the 2013 Act adds another administrative requirement of obtaining special resolution with respect to the preference shares which could not be redeemed by a company. The 2013 Act states that where a company is not in a position to redeem any preference shares or to pay dividend, if any, on such shares in accordance with the terms of issue, it may, with the consent of the holders of three-fourths in value of such preference shares and with the approval of the Tribunal issue further redeemable preference shares equal to the amount due, including the dividend thereon, with respect to the unredeemed preference shares. On the issue of such further redeemable preference shares, the unredeemed preference shares shall be deemed to have been redeemed.
The 2013 Act does not envisage any penalty in respect of non-compliance with the provision of this section, as was prescribed in sub-section (6) and (3) of section 80 and $80 \mathrm{~A}$ of the 1956 Act respectively [section 55 of 2013 Act].

\section{Refusal of registration and appeal against registration}

The provision relating to refusal of registration of transfer or transmission of securities by private and public companies has been separately clarified in the 2013 Act. The private and public companies are required to send notice of refusal within 30 days of the receipt of instrument of transfer, and aggrieved party may appeal to the Tribunal against the refusal within the specified number of days [section 58(2) of 2013 Act].

\section{Further issue of share capital}

The existing requirement of section 81 of the 1956 Act in regard to further issue of capital would no longer be restricted to public companies and would be applicable to private companies also, since subsection 3 of section 81 of the 1956 Act has not been acknowledged in the 2013 Act.

Further, the 2013 Act provides that a rights issue can also be made to the employees of the company who are under a scheme of employees' stock option, subject to a special resolution and subject to conditions as prescribed. Further, the price of such shares should be determined using the valuation report of a registered valuer, which would be subject to conditions as prescribed [section 62 of $2013 \mathrm{Act}$ ].

\section{Issue of bonus shares}

The existing 1956 Act does not have any specific provision dealing with issue of bonus shares although it has referred to the concept of bonus shares at many places. The 2013 Act includes a new section that provides for issue of fully paid-up bonus shares out of its free reserves or the securities premium account or the capital redemption reserve account, subject to the compliance with certain conditions such as authorization by the articles, approval in the general meeting and so on [section 63 of 2013 Act].

\section{Unlimited company to provide for reserve share capital on conversion into limited company}

This section corresponds to section 32 of the 1956 Act and seeks to provide that an unlimited company 
having a share capital may be re-registered as a limited company by increasing the nominal amount of each share, subject to the condition that no part of the increased capital shall be capable of being called up, except in the event and for the purposes of the company being wound up. The 2013 Act further provides that a specified portion of its uncalled share capital shall not be capable of being called up except in the event and for the purposes of the company being wound up [section 65 of 2013 Act].

\section{Reduction of share capital}

The 2013 Act gives cognizance to one of the amendments made in the listing agreement by SEBI. A new clause 24(i) was inserted to the listing agreement which provided that a scheme of amalgamation or merger or reconstruction, should comply with the requirements of section 211(3C) of the 1956 Act. A similar requirement has been introduced in section 66 of 2013 Act, which states that no an application for reduction of share capital shall be sanctioned by the Tribunal unless the accounting treatment, proposed by the company for such a reduction is in conformity with the accounting standards specified in section 133 or any other provision of the 2013 Act and a certificate to that effect by the company's auditor has been filed with the Tribunal.

Further, the 2013 Act clarifies that no such reduction shall be made if the company is in arrears in repayment of any deposits accepted by it, either before or after the commencement of the 2013 Act, or the interest payable thereon.

\section{Power of the company to purchase its own securities}

The existing provision of section 77A of the 1956 Act has been acknowledged by the 2013 Act. The only difference is that the option available to company for a buy-back from odd lots is no longer available [section 68].

The 2013 Act provides flexibility in management and administration by recognizing the electronic mode for notices and voting, which is in line with the MCA's efforts to give cognisance to use of electronic media as evident from a number of green initiatives' introduced recently, maintenance of registers and returns at a place other than the registered office.

\section{REFERENCES}

Circulars or orders issued clarifying the notified sections:

1) General Circular No15/2013 dated 13 September 2013: This provides clarifications on the implementation of sections 2(68), 102, 133 and 180. The clarifications given are as follows:

2) Sub-section (58) of section 2: The Registrar of Companies may register those memorandum and articles of association received till 11 September 2013 as per the definition clause of the private company, under the Companies Act, 1956 without referring to the definition of 'private company' under the said Act.

3) Section 102: All companies which have issued notices of the general meeting on or after 12 September 2o13, the statement to be annexed to the notice shall comply with additional requirements as prescribed in section 102 of the said Act.

4) Section 133: Till the standards of accounting or any addendum thereto are prescribed by the central government in consultation and recommendation of the National Financial Reporting Authority, the existing accounting standards notified under the Companies Act, 1956 shall continue to apply.

5) Section 180: In respect of requirements of special resolution under section 180 of the said Act as against the ordinary resolution required by the Companies Act, 1956, if a notice for any such general meeting was issued prior to 12 September 2013, then such resolution may be passed in accordance with the requirement of the Companies Act, 1956.

6) The general circular No16/2013 dated 18 September 2013: This clarifies that with effect from 12 September 2o13, the relevant provisions of the Companies Act, 1956, which correspond to the provisions of 98 sections of the Companies Act, 2013, brought into force on 12 September .2013, cease to have effect from that date.

7) The general circular No $18 / 2013$ dated 19 November 2013: This clarifies that section 372A of the 1956 Act continues to remain in force till section 186 is notified. 
8) The Companies (Removal of Difficulties) Order, 2013: The MCA has issued the Companies (Removal of Difficulties) Order, 2013 (the 'Order'), which seeks to remove the difficulty which arises on account of notifying the applicability of sections 24 , 58 and 59 of the 2013 Act without constituting the National Company Law Tribunal as per Chapter XXVII of the 2013 Act. Consequently, this order clarifies that "until a date is notified by the central government under sub-section (1) of section 434 of the Companies Act, 2013 (18 of 2013) for transfer of all matters, proceedings or cases to the Tribunal constituted under Chapter XXVII of the said Act, the Board of Company Law Administration shall exercise the powers of the Tribunal under sections 24, 58 and section 59 in pursuance of the second proviso to subsection (1) of section 465 of the said Act." 